\title{
中国生态建设回顾与展望
}

\author{
周立华 ${ }^{1,2, *}$, 刘 洋 1,2 \\ 1 中国科学院科技战略咨询研究院, 北京 100190 \\ 2 中国科学院大学公共政策与管理学院, 北京 100049
}

\begin{abstract}
摘要:伴随着我国四十多年的经济快速发展和生态环境问题的日益严峻,生态建设得到了越来越多的重视,尤其是党的十八大 以来,生态建设的战略地位大大提升。我国生态环境虽然经过了几十年的治理,但是生态环境质量仍然有较大的上升空间,我 国仍处于重大生态工程的密集实施期。总结过去生态建设的发展历程和历史经验, 可为我国未来生态工程的实施和效益提升 提供一些启示和借鉴,促进我国生态文明的建设。通过对新中国生态建设历程的回顾与展望,结果表明: (1) 以 1978 年、2000 年为界, 将新中国生态建设历程划分为生态建设启蒙认识阶段、生态建设启动实施阶段和生态建设快速发展与生态文明发展阶 段。(2) 我国的生态建设取得了巨大成就: 林草植被得到恢复,退化土地得到治理; 山区牧区产业产值不断增加,农牧民收人不 断提高, 脱贫攻坚任务逐步完成; 生态文明和绿色发展理念基本形成。(3) 未来的生态建设需要倾向于通过绿色发展模式,减 少经济系统对生态系统的压力, 以侧面支援生态建设; 认清生态建设自身发展规律, 建立科学的生态工程启动和退出机制, 以避 免生态工程建设时段错位; 提高生态工程的动态管理水平,提升生态工程建设和管理质量。
\end{abstract}

关键词:生态建设;生态工程;历程回顾; 经验启示

\section{Review and prospect of ecological construction in China}

\author{
ZHOU Lihua ${ }^{1,2, *}$, LIU Yang ${ }^{1,2}$ \\ 1 Institutes of Science and Development, Chinese Academy of Sciences, Beijing 100190, China \\ 2 School of Public Policy and Management, University of Chinese Academy of Sciences, Beijing 100049, China
}

\begin{abstract}
With the rapidly economic development for more than 40 years and the increasingly severe problems of ecological environment in China, more and more attention has been paid to ecological construction. The strategic position of ecological construction has been greatly enhanced since the 18th National Congress of the Communist Party of China. Although China's ecological environment governance has been implemented for decades, the quality of ecological environment should still be improved much better, and now, China is still in the intensive implementation period of major ecological projects. Summing up of the development course and historical experience of ecological construction can provide some enlightenment and reference for the implementation and benefit promotion in the future and promote the construction of ecological civilization in China. China's Ecological Construction course has been reviewed in this paper, and three stages had been divided according to the comparison of ecological destruction and ecological protection forces in different periods. Finally, we put forward some suggestions and prospects for the ecological development. Main points were as follows: (1) Bounded by 1978 and 2000 , the course of ecological construction in China was divided into three stages: the initiation stage of ecological construction dominated by ecological damage and lack of ecological protection, the start-up stage of ecological construction with less ecological protection than ecological damage, and the rapid development of ecological construction and ecological civilization stage with more ecological protection than ecological damage. (2) Great achievements have been made in the
\end{abstract}

基金项目:第二次青藏高原综合科学考察研究项目 (2019QZKK0404); 国家重点研发计划项目(2016YFC0500909)

收稿日期: 2020-01-20; 网络出版日期: 2021-02-24

*通讯作者 Corresponding author.E-mail: lhzhou@ casisd.cn 
implementation of China's ecological construction: vegetation of forest and grass has been restored, degraded land has been effectively managed, the industrial output value in mountainous and pastoral areas has been increasing, in the income of farmers and herdsmen has been continuously improved, and the task of overcoming poverty has been gradually completed, and the ecological civilization and green development concept have been formed in the development of ecological projects. (3) In future ecological construction, we should reduce the pressure of the economic system on ecological system through the green development model to support ecological construction laterally. We should recognize the law of ecological construction development and establish a scientific start-up and exit mechanism of ecological project to avoid the dislocation of construction period in ecological project. And, we should also improve the dynamic management level of ecological projects to promote the quality of ecological construction projects and management.

Key Words : ecological construction; ecological projects; course review ; experience enlightenment

新中国成立以来,特别是改革开放 40 年来, 快速的工业化和城市化带动了我国经济的快速发展, 也同时 给我国带来了严重的生态退化问题。例如,资源的掠夺式开发和林草植被的破坏使得荒漠化问题和水土流失 问题日趋严重, 区域生态系统功能不断退化, 导致了我国在 20 世纪末遭受了严重的生态危机, 典型的就是北 方频发的大型沙尘暴和 1998 年长江流域特大洪水 ${ }^{[1]}$ 。这些问题压缩了我国未来发展空间,对社会经济的可 持续发展带来了前所未有的挑战 ${ }^{[2-3]}$ 。重大自然灾害的频发使我国政府开始反思传统的经济发展方式和人 地关系, 促进了绿色发展和可持续发展等发展理念的进一步形成 ${ }^{[4]}$, 生态建设得到了更多的重视。从 20 世纪 末开始, 为了加快修复退化的生态环境, 一批更大规模和投人的生态工程开始实施。特别是党的十八大以后, “生态文明”被纳人到中国特色社会主义事业“五位一体”总体布局之中, “美丽中国” 战略得以确立, 严格高 效的生态文明体制基本形成,生态建设在国家各项工作中达到了前所未有的战略高度和地位 ${ }^{[5]}$ 。

在人类文明演化的历史进程中, 由于农业文明时代的人类生产力水平较低,改造自然的能力较小, 很少有 因人为因素造成的环境灾害, 因此人类对大规模生态建设不具备需求 ${ }^{[6]}$, 真正意义上的大规模生态建设出现 在工业文明时代造成严重的环境问题之后, 19 世纪中叶最先完成工业革命的英国可谓是近代第一个开展生 态建设的国家。当时的英国生态恶化, 污染严重 ${ }^{[7]}$,城市肮脏 ${ }^{[8]}$ 。为了改善环境质量, 英国政府一方面开展 环境治理工程, 恢复生态和改善人居环境 ${ }^{[9]}$; 另一方面通过环境立法建立起环境管理的长效治理机制, 逐渐 实现了环境质量的好转, 流行疾病下降, 保障了民众健康 ${ }^{[10]}$ 。欧美发达国家工业化进程早, 相应的生态建设 起步也较早, 生态治理恢复时间长, 从而生态环境质量较好, 如今已较少实施大型生态工程, 并形成了一套成 熟完善的环境法律体系 ${ }^{[11]}$ 。作为生态建设内容之一的环境法律体系的发展是一个循序渐进的过程, 虽然欧 美发达国家早在 19 世纪中后期就初步建立起了环境法律体系,但标准低、力度小、不全面, 直到 20 世纪 6070 年代才逐渐发展成一套成熟完善的环境法律和治理体系,环境政策工具也逐渐实现了由行政管控向市场 调控和自愿参与的转变 ${ }^{[12]}$ 。

我国生态环境虽然经过了几十年的治理,但是生态环境质量仍然有较大的上升空间, 总体上我国现在仍 处于重大生态工程的密集实施期和生态文明建设的重点发展期。总结我国过去生态建设的发展历程和历史 经验, 能够为科学研判未来生态建设的趋势和提高未来生态工程效益提供一些启示和借鉴, 有利于促进我国 生态文明的建设。目前的已有相关研究中, 许多学者对我国生态文明建设历程进行了深人研究 ${ }^{[13-16]}$, 侧重论 述了习近平生态文明思想的起源和发展, 较少关注生态工程的发展历程, 难以准确认识新中国 70 余年来生态 环境质量和生态建设强度的变化情况。基于此, 为了提高未来生态建设的质量, 加快生态文明建设, 本文依据 各阶段生态破坏和生态保护力量对比情况, 对新中国生态建设的历程进行了阶段划分, 并总结分析了过去生 态建设所取得的成就和经验, 以期对我国未来的生态建设提供一些启示和借鉴。

\section{1 生态建设历程的阶段分析}

我国生态建设历程的阶段划分主要依据不同时期生态破坏和生态保护力量对比情况, 依此我国生态建设 
经历了从无到有、从慢到快的历程。1978 年三北防护林工程实施之前, 我国少有大型生态建设工程, 以工农 业发展带来的生态破坏为主,生态保护缺位,划分为生态建设的启蒙认识阶段; 1978-2000 年左右,大型生态 建设工程开始实施,但让步于经济发展大局,生态破坏严重,生态保护力量相对较小,划分为生态建设的启动 实施阶段;2000 年以后,随着更多更大的生态建设工程的实施和经济发展理念和方式的转变,生态破坏力量 趋小,生态保护力量趋大并超过生态破坏力量,生态建设进人快速发展与生态文明发展阶段。

1.1 生态建设的启蒙认识阶段 (1949-1978 年)

该阶段的生态环境状况是: 生态环境持续退化, 鲜有生态建设, 但由于经济发展处于起步阶段,生态退化 速度也较慢,总体状况良好。具体分为以下三个时期:

\subsection{1 生态平稳时期 (1949-1957 年)}

这段时期我国的主要任务是巩固政权和恢复经济。1953-1957 年,我国开始实行第一个五年计划和社 会主义改造。总体来看,整个经济发展基调是比较稳健的,战后的经济烂摊子逐渐得到恢复。这一时期,我国 生态环境虽面临退化风险,尤其是西北生态脆弱区,但总体状况良好, 自然灾害的发生频率较低,成灾强度较 小,生态建设不是国家重点工作。形成这种局面的主要原因在于当时较小的经济规模和稳健的经济政策避免 了给生态环境带来过多压力。1952 年我国工农业总产值 (相当于当年 GDP) 为 827.2 亿元, 1957 年上升至 1387.9 亿元。另一方面,稳健的经济政策也避免了因违背自然规律而带来的大规模生态破坏。

\subsection{2 生态恶化时期 (1958-1966 年)}

该时期分为以“大跃进”和“人民公社”为代表的运动时期 (1958-1960 年), 以及后续调整时期 (1961一 1966 年)。在 “赶英超美” 思想的驱动下, 生态环境受到了很大破坏, 尤其是森林和草原。以全民大炼钢铁为 例, 许多地方不顾当地实际情况, 为了获取炼钢的燃料, 不顾炼钢质量, 在没有焦炭和煤炭的情况下就用木炭 替代, 导致大面积森林被砍伐, 森林遭到严重的破坏,一些地区的“青山”变成了“秃山” “17]。除此之外,农牧 业的快速发展也是导致森林和草原锐减的重要原因。过快增长的人口导致了大规模的 “开荒”运动, 使得原 来的森林、草原和湿地变成了耕地。特别是北方农牧交错区因为过度放牧导致沙漠化发展较为严重 ${ }^{[18]}$ 。

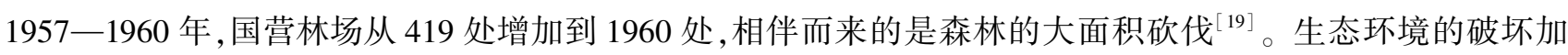
剧了 1959-1961 三年旱灾成灾强度,根据《中国水旱灾害》记载, 1959-1961 年间,受灾面积达 $3659.7 \mathrm{hm}^{2}$, 粮 食减产 1177.1 万 $\mathrm{t}$, 远远超过 1949-1958 年间的 $839.4 \mathrm{hm}^{2}$ 和 339.7 万 $\mathrm{t}$ 。

\subsection{3 生态加剧恶化时期 (1966-1978 年)}

这一时期, 我国总人口从 7.35 亿增长到 9.56 亿, 年均增长 1840 万, 1966-1976 年中,除了 $1967 、 1968$ 年 出现经济负增长以外,其余年份均为正增长, 10 年间经济总量年平均增长率达到 $7.1 \%$ 。在人口与经济增长 的双重压力和 “以粮为纲” 的政策导向下,促使人们开层更多的耕地,使森林、草原等重要生态系统面积进一 步减少 ${ }^{[20]}$ 。随着生态退化问题的日益加剧, 我国开始认识到环境问题的重要性, 并参加了 1972 年在瑞典斯 德哥尔摩举办的人类环境大会。1973 年首次召开了全国环境保护会议,标志着我国环境管理事业的起 步 ${ }^{[21]}$ 。从此以后, 环境管理被纳人政府职能, 我国才有了真正意义上的生态建设工程, 但大规模的生态建设 工程是在改革开放后才陆续展开。

\section{2 生态建设的启动实施阶段 (1978-2000 年)}

改革开放以来,伴随着经济的飞速增长, 长期生态破坏的积累, 20 世纪 90 年代我国生态环境出现了严重 退化,发生了一些空前的自然灾害,如 1993 年造成 85 人死亡的甘肃金昌特强沙尘暴 ${ }^{[22]}$, 1994 年造成 1216 人 死亡的浙江瑞安登陆的 9417 号台风 ${ }^{[23]}, 1998$ 年影响大半个中国、死亡 4000 多人的特大洪水。干旱区的沙尘 暴和湿润区的洪涝灾害是对我国影响较大的生态危机。据统计, 50 年间具有社会影响的重大沙尘暴发生次 数逐年增加, 20 世纪 50 年代发生 5 次,60 年代发生 8 次,70 年代发生 13 次, 80 年代发生 19 次,90 年代发生 23 次 ${ }^{[24]}$ 。20 世纪 80 年代以来, 由于上游森林的破坏和中下游的围湖造田愈演愈烈, 长江流域几乎年年出现 大洪灾, 特别是 1998 年发生的长江特大洪灾, 死亡 4150 多人, 直接经济损失 2551 亿元人民币。日益严峻的 
生态问题,促使我国逐渐认识到生态建设的重要性。

在此背景下,我国启动了一批重大生态建设工程,使得该阶段具有生态破坏和生态保护并存的特点。由 于前期 (1978-1987 年) 启动建设的生态建设工程较少,多数生态工程都密集启动于后期 (1988-2000 年), 根据生态工程实施密度可将我国生态建设的启动实施阶段分为起步实施期 (1978-1987 年) 和密集实施期 （1988-2000 年）。我国最早实施的重大生态工程是 1978 年启动的三北防护林工程,因规模宏大、效益明显， 被称为我国当代的 “绿色长城” ${ }^{[25]}$ 。三北防护林工程之所以能与改革开放同步启动, 与三北地区 (东北、华 北、西北)干旱半干旱的脆弱生态环境有关,这些地区生态退化程度远高于当时全国平均水平, 治理形势更加 迫切。随后,由于劳动密集型和资源密集型产业的快速发展,生态环境问题日益严重。在此背景下,一大批重 大生态工程陆续启动实施。平原绿化工程 (1988 年)、沿海防护林体系工程 (1988 年)、长江中上游防护林工 程(1989 年)、天然林保护工程(1998 年)相继启动, 通过对森林生态系统的保护, 对防治沙尘暴、减少水土流 失、保障农业发展起到了重要作用 (表 1$)^{[26-28]}$ 。

表 1 我国 1978-2000 年间实施的重大生态工程

Table 1 Major ecological projects implemented in China during 1978-2000

\begin{tabular}{|c|c|c|c|c|c|}
\hline $\begin{array}{l}\text { 工程名称 } \\
\text { Project name }\end{array}$ & $\begin{array}{c}\text { 开始时间 } \\
\text { Starting time }\end{array}$ & $\begin{array}{c}\text { 工程类别 } \\
\text { Project category }\end{array}$ & $\begin{array}{l}\text { 工程背景 } \\
\text { Project background }\end{array}$ & $\begin{array}{l}\text { 工程内容 } \\
\text { Project content }\end{array}$ & $\begin{array}{c}\text { 工程功能 } \\
\text { Project function }\end{array}$ \\
\hline $\begin{array}{l}\text { 三北防护林工程 } \\
\text { Three-north shelter } \\
\text { forest project }\end{array}$ & 1978 & 森林生态工程 & $\begin{array}{l}\text { 区域气候干旱, 林草植被稀 } \\
\text { 少; 过度开垦、过度放牧进一 } \\
\text { 步破坏了森林和草原生态系 } \\
\text { 统,使该地区生存环境更加 } \\
\text { 恶劣 }\end{array}$ & $\begin{array}{l}\text { 以恢复植被为核心, 根据工程 } \\
\text { 区内不同治理功能的需要, 形 } \\
\text { 成一个主要包括草牧场防护 } \\
\text { 林、水土保持体、农田防护林 } \\
\text { 以及经济速生林的防护林 } \\
\text { 体系 }{ }^{29]}\end{array}$ & $\begin{array}{l}\text { 防沙治沙 } \\
\text { 水土保持 }\end{array}$ \\
\hline $\begin{array}{l}\text { 平原绿化工程 } \\
\text { Plain greening project }\end{array}$ & 1988 & 森林生态工程 & $\begin{array}{l}\text { 长期不合理的耕作方式, 我国 } \\
\text { 土壤肥力逐渐下降,农作物更 } \\
\text { 易受自然灾害影响而减产,农 } \\
\text { 业发展面临威胁 }\end{array}$ & $\begin{array}{l}\text { 在我国粮食生产的重点平原 } \\
\text { 地区建造农田林网防护工程, } \\
\text { 抵御干热风、霜冻等灾害性 } \\
\text { 气候 }\end{array}$ & 农田防护 \\
\hline $\begin{array}{l}\text { 沿海防护林体系工程 } \\
\text { Coastal shelterbelt } \\
\text { system project }\end{array}$ & 1988 & 森林生态工程 & $\begin{array}{l}\text { 台风、海啸、风暴潮等自然灾 } \\
\text { 害频发,严重威胁到沿海地区 } \\
\text { 经济发展和人民群众生命财 } \\
\text { 产安全 }\end{array}$ & $\begin{array}{l}\text { 构建由防风固沙林、水土保持 } \\
\text { 林、水源涵养林、农田防护林 } \\
\text { 和其他防护林等 } 5 \text { 类防护林 } \\
\text { 组成的 “防护林综合体”, 防 } \\
\text { 御沿海地区台风、霜冻、水土 } \\
\text { 流失等自然灾害 }[23]\end{array}$ & $\begin{array}{l}\text { 防风防潮 } \\
\text { 水土保持 }\end{array}$ \\
\hline $\begin{array}{l}\text { 长江 中上游防护林 } \\
\text { 工程 } \\
\text { Shelterbelt project in } \\
\text { upper-middle reaches } \\
\text { of the Yangtze River }\end{array}$ & 1989 & 森林生态工程 & $\begin{array}{l}\text { 长期不合理耕作和森林破坏 } \\
\text { 导致中上游水源涵养功能下 } \\
\text { 降,使得长江流域水旱、泥石 } \\
\text { 流灾害更加严重 }\end{array}$ & $\begin{array}{l}\text { 造林 (分为人工造林、封山育 } \\
\text { 林和飞播造林三种)、低效林 } \\
\text { 改造、能力建设 (包括监测体 } \\
\text { 系建设、科技推广和科技培训 } \\
\text { 等) }[30]\end{array}$ & 水土保持 \\
\hline $\begin{array}{l}\text { 天然林保护工程 } \\
\text { Natural forest } \\
\text { protection project }\end{array}$ & 1998 & 森林生态工程 & $\begin{array}{l}\text { 天然林资源遭到了严重的砍 } \\
\text { 伐, 水土流失严重, 河流含沙 } \\
\text { 量剧增; 长江发生了 } 1998 \text { 年 } \\
\text { 特大洪水 }\end{array}$ & $\begin{array}{l}\text { 禁止工程区内天然林资源的 } \\
\text { 采伐,并同时对因滥砍滥伐而 } \\
\text { 形成的荒山进行造林 }{ }^{[31]}\end{array}$ & 水土保持 \\
\hline
\end{tabular}

1.3 生态建设快速发展与生态文明发展阶段 (2000 年一至今)

自 1983 年全国第二次环境保护会议将“保护环境” 定位为基本国策以来, 从 2007 年党的十七大将“科学 发展观”写人党章, 到 2012 年党的十八大将“生态文明” 纳人中国特色社会主义总布局, 再到 2015 年党的十 八届五中全会提出“创新、协调、绿色、开放、共享” 的新发展理念,进而到 2018 年“生态文明” 写人我国宪法, 21 世纪里我国生态建设的战略地位不断提升; 从 2002 年的退耕还林、退牧还草工程, 到 2015 年的国家公园 试点工程, 再到 2016 年山水林田湖草生态保护修复试点工程,21 世纪里重大生态工程继续出台,生态环境建 设进人到了快速发展的新时期。

1.3.1 生态建设加速强化期( $2000-2012$ 年) 
进人 21 世纪以来, 我国又启动了一批新的重大生态工程。退耕还林工程 (2002 年)、退牧还草工程 (2002 年)、国家公园试点工程 (2015 年)、山水林田湖草生态保护修复试点工程 (2016 年) 先后启动实施, 推动着国 家生态建设向纵深方向发展 (表 2)。与 20 世纪末的重大生态工程相比, 新时期重大生态工程资金投人和建 设规模都大大提高。退耕还林工程自启动以来, 到 2019 年累计投人超过 5000 亿元, 实施退耕还林还草 3400 万 $\mathrm{hm}^{2}$,工程区森林覆盖率平均提高了 4 个多百分点; 草原生态保护补助奖励政策自 2011 年实施以来, 8 年来 累计投人草原生态补奖资金 1326 亿元。草原治理也纳人了国家生态建设的重点对象,这对阻止草原继续退 化具有重要意义。生态治理理念越来越趋于系统性和整体性,生态工程类型趋变为区域综合性治理工程,注 重生态系统的整体性和治理方式的多样性 ${ }^{[32]}$ 。通过密集实施更大规模的生态工程, 我国生态建设进人到快 速发展的新时期。

表 22000 年以来我国实施的重大生态工程

Table 2 Major ecological projects implemented in China since 2000

\begin{tabular}{|c|c|c|c|c|c|}
\hline $\begin{array}{l}\text { 工程名称 } \\
\text { Project name }\end{array}$ & $\begin{array}{l}\text { 开始时间 } \\
\text { Starting time }\end{array}$ & $\begin{array}{c}\text { 工程类别 } \\
\text { Project category }\end{array}$ & $\begin{array}{l}\text { 工程背景 } \\
\text { Project background }\end{array}$ & $\begin{array}{l}\text { 工程内容 } \\
\text { Project content }\end{array}$ & $\begin{array}{c}\text { 工程功能 } \\
\text { Project function }\end{array}$ \\
\hline $\begin{array}{l}\text { 退耕还林工程 } \\
\text { Grain for green project }\end{array}$ & 2002 & 森林生态工程 & $\begin{array}{l}\text { 长期毁林开荒和进行陡坡地、 } \\
\text { 沙化地耕种带来日益突出的 } \\
\text { 生态问题, 比如水土流失、土 } \\
\text { 地荒漠化等 }\end{array}$ & $\begin{array}{l}\text { 通过补贴, 将不适宜耕作的耕 } \\
\text { 地 (比如沙化地、陡坡地) 进 } \\
\text { 行植树种草, 包括在宜林荒山 } \\
\text { 荒地造林 }{ }^{333]} \text {; 补贴通常包括 } \\
\text { 退耕造成的粮食损失和造林 } \\
\text { 综合费用两部分 }\end{array}$ & $\begin{array}{l}\text { 防沙治沙、 } \\
\text { 水土保持 }\end{array}$ \\
\hline $\begin{array}{l}\text { 退牧还草工程 } \\
\text { Returing grazing land to } \\
\text { grassland project }\end{array}$ & 2002 & 草原生态工程 & $\begin{array}{l}\text { 草原退化严重, 气候干旱, 河 } \\
\text { 流萎缩, 沙尘暴频发, 生态环 } \\
\text { 境恶化; 牧民迫于生计压力, } \\
\text { 仍然超载放牧, 草原难以休养 } \\
\text { 生息 }\end{array}$ & $\begin{array}{l}\text { 禁牧休牧、围栏、补播和建设 } \\
\text { 人工草场等 }{ }^{[34]} \text {; 根据不同草 } \\
\text { 原类型和不同建设内容对牧 } \\
\text { 民给予不同标准的补贴, 确保 } \\
\text { 牧民在“还草” 的过程中不受 } \\
\text { 损, 自觉保护草原 }\end{array}$ & 防沙治沙 \\
\hline $\begin{array}{l}\text { 国家公园试点工程 } \\
\text { National park } \\
\text { pilot project }\end{array}$ & 2015 & 综合性生态工程 & $\begin{array}{l}\text { 各类保护区分类分级不清、空 } \\
\text { 间交叉重叠、管理权属分散; } \\
\text { 服务主体功能区、国土空间开 } \\
\text { 发保护等战略 }\end{array}$ & $\begin{array}{l}\text { 整合现有自然保护区建立国 } \\
\text { 家公园, 把原来碎片化、孤岛 } \\
\text { 化的自然生态系统完整连接 } \\
\text { 起来 }\end{array}$ & $\begin{array}{l}\text { 综合保护、 } \\
\text { 休憩教育等 }\end{array}$ \\
\hline $\begin{array}{l}\text { 山水林田湖草生态保 } \\
\text { 护修复试点工程 } \\
\text { Pilot project of } \\
\text { ecological protection and } \\
\text { restoration of whole } \\
\text { ecosystem }\end{array}$ & 2016 & 综合性生态工程 & $\begin{array}{l}\text { “山水林田湖草是一个生命共 } \\
\text { 同体” 概念的提出; 区域生态 } \\
\text { 环境普遍面临综合性生态 } \\
\text { 问题 }\end{array}$ & $\begin{array}{l}\text { 注重生态系统整体性和区域 } \\
\text { 差异 性, 综 合治理, 分 类 } \\
\text { 施策 }{ }^{[35]}\end{array}$ & 综合保护 \\
\hline
\end{tabular}

1.3.2 生态文明建设时期 (2012 年一至今)

2012 年,党的第十八次全国代表大会在北京召开,生态文明建设被纳人 “五位一体” 的总体布局, 这标志 着我国进人了生态文明建设时期。2013 年, 习近平总书记在哈萨克斯坦纳扎尔巴耶夫大学向世界全面阐述 了 “两山论” : “我们既要绿水青山,也要金山银山。宁要绿水青山,不要金山银山, 而且绿水青山就是金山银 山”。2015 年, 国务院出台了《生态文明体制改革总体方案》,规划了未来生态文明建设的蓝图。2017 年, 党 的十九大报告在生态文明建设部分着重强调了绿色发展, 明确了绿色发展是生态文明建设的重要路径。2018 年, “生态文明”得到了宪法的保障。这一时期,生态环境处于社会经济发展的突出位置,在经济发展与环境 保护发生冲突时, 优先考虑生态环境; 另一方面, 经济发展进人新常态, 国家更加强调转变经济发展方式, 推动 产业结构升级, 实现绿色发展, 从根本上减轻发展带给生态环境的压力。各项重大生态工程继续推进, 生态文 明制度建设不断完善,推动我国生态环境进一步好转。

\section{2 生态建设的成就分析}

新中国多年来的生态建设在生态恢复、社会经济效益和转变发展理念方面取得了巨大成就: 林草植被得 
到恢复,退化土地得到治理; 山区牧区产业产值不断增加,农牧民收人不断提高,脱贫攻坚任务逐步完成; 生态 文明和绿色发展理念基本形成。

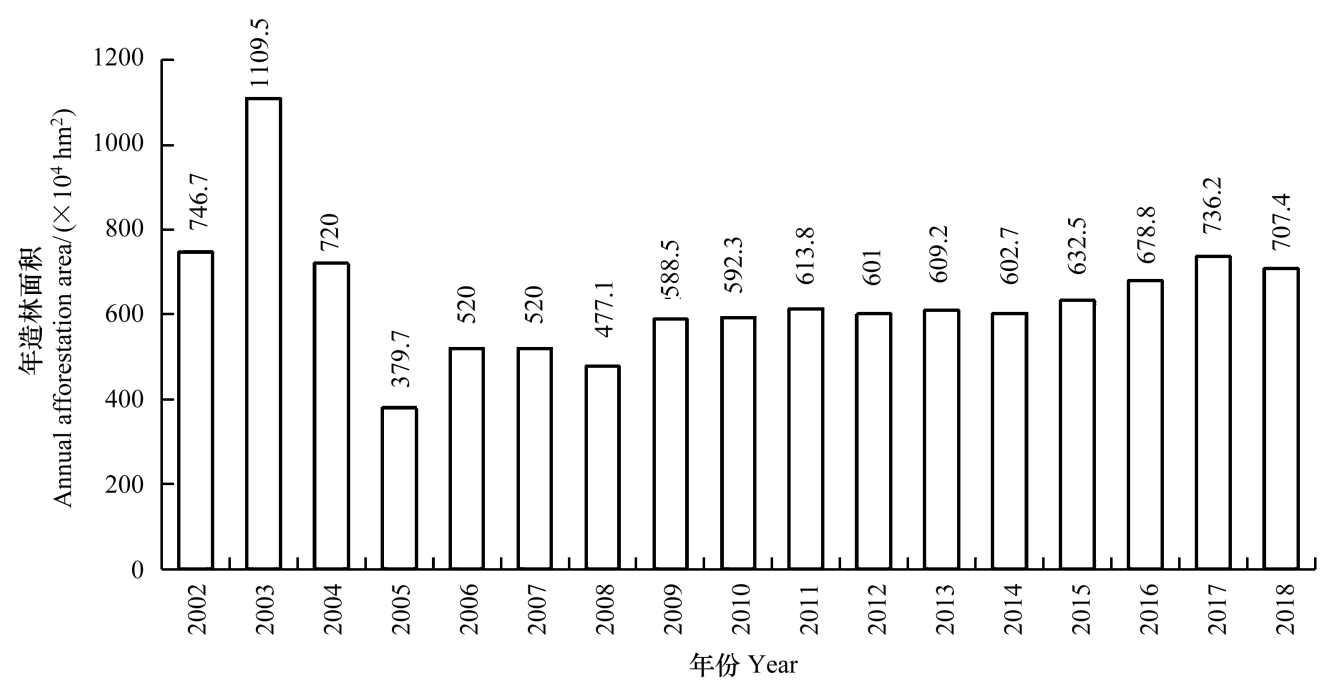

图 1 中国年造林面积变化情况

Fig.1 Annual afforestation area in China from 2002 to 2018

\section{1 生态恢复效果显著}

林草植被恢复。建国初期, 全国森林面积仅为 8280 万 $\mathrm{hm}^{2}$, 森林覆盖率为 $8.6 \%{ }^{[36]}$, 根据历次全国森 林资源清查报告, 1977-1981 年间全国森林面积扩大 到 11527 万 $\mathrm{hm}^{2}$,森林覆盖率为 $12 \%, 2000$ 年,全国森林 面积 15894 万 $\mathrm{hm}^{2}$,森林覆盖率为 $16.55 \%, 2019$ 年,全 国森林面积达到 22000 万 $\mathrm{hm}^{2}$, 森林覆盖率达到 $22.96 \%$ 。21 世纪以来,据历年中国国土绿化状况公报 统计,我国年造林面积 300 万 $\mathrm{hm}^{2}$ 以上,其中 2003 年峰 值达到 1109.5 万 $\mathrm{hm}^{2}$, 是森林覆盖率加速上升的重要原 因(图 1)。截止 2018 年,我国人工林保存面积 6933 万 $\mathrm{hm}^{2}$, 居世界首位, 占世界人工林总面积的 $27 \%$ 。我国

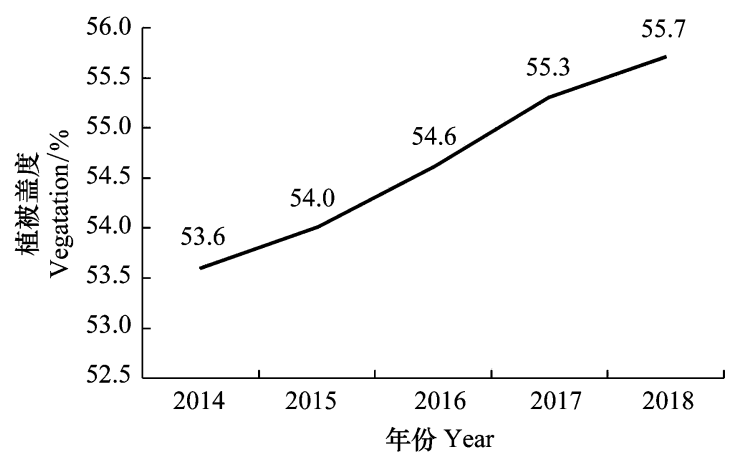

图 2 中国草原综合植被盖度变化情况

Fig. 2 Grassland comprehensive vegetation coverage in China from 2014 to 2018 草原总面积大约为 4 亿 $\mathrm{hm}^{2}$, 其中退化面积从 1989 年 的 6670 万 $\mathrm{hm}^{2}$ 扩大到 2000 年的 1.35 亿 $\mathrm{hm}^{2}$, 到 2003 年, 全国 $90 \%$ 以上的草原存在不同程度退化。近 5-10 年之内草原生态总体有所改善, 草原综合植被盖度连续五年上涨, 从 2014 年的 $53.6 \%$ 上升到了 2018 年的 $55.7 \%$,天然草原鲜草总产量连续稳定在 10 亿 $\mathrm{t}$ 以上。通过持续的草原治理, 我国有望在 2025 年转变草原退 化的局面(图 2)。

退化土地治理。根据国家相关部委的公开资料,在水土保持方面,水土流失面积从建国初期的 153 万 $\mathrm{km}^{2}$ 逐渐增加到 90 年代初的 367 万 $\mathrm{km}^{2}$, 再逐渐下降到 2011 年的 295 万 $\mathrm{km}^{2}, 2018$ 年的 274 万 $\mathrm{km}^{2}$ 。在防沙 治沙方面, 荒漠化面积从建国初期的 60 万 $\mathrm{km}^{2}$ 增加到 1999 年的 267.42 万 $\mathrm{km}^{2}$, 此后出现逆转现象, 面积开始 逐渐下降(图 3)。

2.2 社会经济效益明显提升

生态建设,尤其是国家生态建设工程的实施, 促进了当地产业结构的转型升级,产业产值大幅增加。以恢 复森林为主的山区除了发展起木材加工业, 还培育了林下种养殖、生态旅游等林副业 ${ }^{[37]}$; 以恢复草原为主的 
牧区积极转变生产经营方式,采用舍饲圈养, 优化畜群 结构, 改良牲畜品种, 走向了集约的畜牧业发展方 式 ${ }^{[38-39]}$ 。产业的转型升级进一步带来了就业结构的转 型升级, 提高了当地农牧民的收人, 特别是国家生态建 设工程区基本都位于 “老少边穷” 地区,生态工程建设 对这些地区的百姓脱贫致富具有更特殊的意义。比如 通过林业生态工程, 大量剩余劳动力从原来种植业转移 到林业, 转移到工业和服务业 (外出务工), 转移到工程 自身建设用工上,这些转移有效增加了当地农牧民的收 人,推动了当地百姓脱贫致富。

2.3 绿色发展理念基本形成

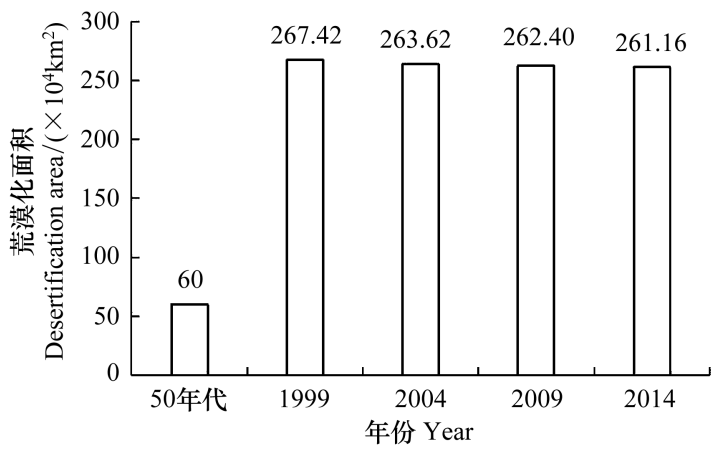

图 3 我国荒漠化面积变化情况

Fig.3 Desertification area in China from 1950s to 2014

以 1978 年三北防护林工程为标志, 我国的发展理 念从以牺牲环境作为发展代价进入到发展兼顾环境保护的新时期,此后保护生态环境的发展理念不断得到深 化。改革开放后至 20 世纪末, 经济刚刚起步,迫于发展压力,生态保护让位于发展大局,总体看来生态保护力 度较小。21 世纪以来, 在深刻认识到长期生态破坏带来的严峻问题后,生态保护力度逐步加强, 环境治理理 念逐渐从未端治理转变为源头防控,生态经济、绿色经济等新的发展理念不断提出。2007 年胡锦涛总书记提 出了科学发展观,2015 年习近平总书记提出了“创新、协调、绿色、开放、共享” 的新发展理念,如今,绿色发展 已成为中国特色社会主义新时代的基本发展理念 ${ }^{[40]}$ 。

\section{3 生态建设的经验启示}

新中国多年来的生态建设虽然在各方面都取得了巨大成就,但是在建设过程中也出现了一些新的问题， 必须认真总结这些问题背后的经验启示, 服务于我国未来的生态建设。

\section{1 转变发展方式,实现绿色发展}

在传统粗放的发展方式下,经济系统和生态系统之间不协调,经济系统给生态系统造成的巨大压力导致 了各类环境问题的产生。传统粗放的发展方式往往选择先污染后治理的道路,带来的后果就是这些环境问题 无法得到根本解决, 而且解决成本十分高昂。我国 70 余年生态建设的历程证明了一个根本的道理: 发展经济 不能以牺牲生态环境为代价。短期来看,牺牲环境确实可以换来一些经济发展,但是长期来看,生态环境是经 济发展的重要物质基础,基础受损,未来的发展也将遭受损失。许多发达国家的实践也证明,环境保护与经济 发展是可以兼顾的。环境系统与社会经济系统之间存在着相互作用和影响,因此要转变传统粗放的发展方 式,实现绿色发展,从源头上减少社会经济系统对环境系统的压力,提高社会经济系统与环境系统的协调 度 ${ }^{[41]}$, 从根本上减少生态环境问题的产生。

\section{2 生态建设具有自身发展规律}

生态建设具有自身的生命周期,其酝酿、启动、加速和退出过程都与客观的生态环境质量密切相关。人类 社会对生态系统的不断开发利用的过程酝酿了生态建设的需求, 当人类活动过度影响生态系统而导致生态危 机产生,并影响到人类发展时,生态建设开始启动,经过一段时期的建设,发现以前的生态破坏积重难返,于是 生态建设开始加速, 当生态建设达到预期目标时,生态建设将开始退出。对我国而言,参照生态建设四个时期 的特点, 可以作如下划分: 新中国成立到改革开放前是生态建设酝酿期, 改革开放后到 20 世纪末是生态建设 起步期,21 世纪进入生态建设加速期,按照“美丽中国” 的时间表,2050 年后生态建设可能进入退出期。过去 的生态工程建设中, 往往忽略了客观环境的变化, 缺乏对生态工程实施过程的动态调整, 影响到生态工程效益 的最优化。因此,生态工程需要设置一个主客观相统一的准人和退出门槛, 建立起科学的生态工程启动和退 出机制。 
3.3 克服管理和技术上的难题, 提高重大生态工程建设质量

自国家重大生态工程启动以来, 几十年内取得了显著的成就, 但在工程建设中也不可避免地出现了一些 管理和技术上的问题。这些问题主要集中在工程规划粗放、程序不规范、公众参与较少、资金投人不足、监管 体系不严、技术支撑能力不强等方面 ${ }^{[42-47]}$ 。在未来生态工程建设中要认真汲取之前的经验教训, 提高生态工 程的政府管理水平。一方面, 必须加强工程规划出台前的实地调研, 合理设置生态恢复目标和生态补偿标 准 ${ }^{[48]}$; 提高工程区内公众参与度, 充分调动群众的积极性 ${ }^{[49]}$; 对工程实行精细化统一管理 ${ }^{[50]}$, 努力研发新技 术 ${ }^{[51]}$, 提高重大生态工程后期管理质量。另一方面, 针对生态工程实施过程中由于时间变化导致的新情况和 新问题, 必须强化政府管理部门对工程和政策的动态评估和动态管理, 及时针对新情况和新问题对现有生态 工程和生态政策进行适时适度调整。

\section{4 结论和讨论}

新中国生态建设的历程可以分为以下三个阶段:一是,生态建设启蒙认识阶段 (1949-1978 年) : 生态破 坏为主, 鲜有生态保护; 二是, 生态建设启动实施阶段 (1978-2000 年) : 重大生态工程起步, 生态破坏和生态 保护并存, 且生态保护小于生态破坏; 三是,生态建设快速发展与生态文明发展阶段 (2000 年一至今) : 生态保 护大于生态破坏, 生态环境快速好转。通过回顾我国生态建设的发展历程, 比较清晰地展现了 70 余年来我国 生态环境质量和生态建设强度的变化情况。

生态建设取得了良好的生态、经济和社会效益, 同时促进了我国发展理念的优化升级: 林草植被得到恢 复, 退化土地得到治理; 山区牧区产业产值不断增加, 农牧民收人不断提高, 脱贫攻坚任务逐步完成; 生态文明 和绿色发展理念基本形成。生态建设在取得巨大成就的同时也在建设过程中出现了一些问题:粗放的发展方 式造成了巨大的生态破坏; 缺乏科学的生态工程启动和退出机制、生态工程的规划和管理水平较低导致生态 工程效益受到影响。

我国生态建设总结出的最根本的经验启示就是要转变自然伦理观, 转变经济发展方式, 实现绿色发展, 从 源头上减少生态破坏。按照经济学理论,一个国家在从农业国向工业国转变的初期, 由于缺少技术和资本, 主 要依靠的生产要素是劳动力和自然资源, 往往形成粗放的经济发展方式, 从而导致经济发展与生态环境不协 调, 加剧了生态退化程度; 当完成工业基础积累、实现生产要素转型 (绿色发展) 以后, 经济发展速度与生态环 境退化便不存在明显正相关关系。我国正处于经济转型阶段, 是否转型成功, 对解决我国环境问题和提高环 境质量至关重要。

生态建设一定要遵循科学规律。生态建设的启动和退出与生态环境质量密切相关, 生态建设随生态环境 质量的恶化开始,也会随生态环境质量的复原而结束, 要建立起科学的生态工程启动、调整和退出机制。国家 重点生态工程规划一定要以工程区实际生态状况为基础, 避免脱离实际盲目提高生态建设目标, 比如西北干 旱地区的预期森林覆盖率的设置如何才能既满足民众期望又符合当地生态实际。同时, 针对生态工程实施中 出现的管理和技术上的问题, 要通过动态评估和管理, 及时调整政策。比如我国北方草原的禁牧政策, 在初期 对恢复草原植被治理草原退化具有显著效果, 实施禁牧政策后草原植被的数量、高度、密度同禁牧前相比大幅 提高。但生态学家的定位观测研究结果表明, 长期围封的草地会出现新的退化现象, 大多数草地区域围封 6-10 年后出现土壤固碳速率和物种多样性下降的情况。此外, 长期禁牧还可能会导致局部区域火灾风险的 增加。我国北方的一些草原禁牧已近 20 年, 应该在科学评价草原利用与禁牧成效基础上, 对禁牧政策进行适 当科学调整。

今后的研究要重点关注如何构建生态工程的动态管理机制, 及时发现和解决工程实施过程中的问题; 如 何构建科学的生态工程启动和退出机制, 以避免生态工程建设时段错位; 如何继续完善我国生态文明建设机 制, 提高国家生态治理能力。 


\section{参考文献 (References) :}

[ 1 ] 钱正安, 宋敏红, 李万元. 近 50 年来中国北方沙尘暴的分布及变化趋势分析. 中国沙漠, 2002, 22(2): 106-111.

[ 2 ] 吕永龙, 王一超, 苑晶晶, 贺桂珍. 可持续生态学. 生态学报, 2019, 39(10): 3401-3415.

[ 3 ] 赵其国, 黄国勤, 马艳芹. 中国生态环境状况与生态文明建设. 生态学报, 2016, 36(19) : 6328-6335.

[ 4 ] 陈盼, 施晓清. 基于文献网络分析的生态文明研究评述. 生态学报, 2019, 39(10): 3787-3795.

[ 5 ] 高世楫, 王海芹, 李维明. 改革开放 40 年生态文明体制改革历程与取向观察. 改革, 2018, (8) : 49-63.

[6] 陈志强. 开展生态环境史研究 拓宽解读人类历史的视角. 历史研究, 2008, (2): 38-41.

[ 7 ] Cavert W M. The environmental policy of Charles I: coal smoke and the English monarchy, 1624-40. Journal of British Studies, 2014, 53(2) : 310-333.

[ 8 ] Palliser D M. Civic mentality and the environment in Tudor York. Northern History, 1982, 18(1) : 78-115.

[ 9 ] Jørgensen D. Local government responses to urban river pollution in late medieval England. Water History, 2010, 2(1) : 35-52.

[10］李宏图. 英国工业革命时期的环境污染与治理. 探索与争鸣, 2009, (2) : 60-64.

[11] 杜群. 可持续发展与中国环境法创新一一环境法律体系的重塑. 北京师范大学学报: 人文社会科学版, 2001, (5): 132-139.

[12] Glicksman R L, Chapman S B. Regulatory Reform and (Breach of) the Contract with America: Improving Environmental Policy or Destroying Environmental Protection? Kansas Journal of Law \& Public Policy, 1996, Winter: 9-27.

[13] 张忠跃, 胡炅坊. 中国生态文明建设历程回顾与经验分析. 长春师范大学学报, 2020, 39(1) : 39-41.

[14］黄承梁. 中国共产党领导新中国 70 年生态文明建设历程. 党的文献, 2019, (5) : 49-56.

[15］邱寅莹. 当代中国生态文明建设历程与启示. 太原理工大学学报: 社会科学版, 2017, 35(5): 7-11.

[16] 周光迅, 郑玥. 从建设生态浙江到建设美丽中国——习近平生态文明思想的发展历程及启示. 自然辩证法研究, 2017, 33(7) : 76-81.

[17] 陶格斯. 中国环境问题的历史变化. 环境科学与管理, 2009, 34(8): 188- 192.

[18］宋乃平, 张凤荣. 重新评价“以粮为纲”政策及其生态环境影响. 经济地理, 2006, 26(4) : 628-631.

[19］杨津涛. 今天是植树节, 说说日本森林覆盖率极高的历史经验. (2019-03-12) [ 2019-08- 10]. https://new. qq. com/omn/20190312/ 20190312A09SII.html.

[20］曹雪, 金晓斌, 王金朔, 缪丽娟, 周寅康. 近 300 年中国耕地数据集重建与耕地变化分析. 地理学报, 2014, 69(7)：896-906.

[21] 叶汝求. 改革开放 30 年环保事业发展历程一一解读历次国务院关于环境保护工作的决定. 环境保护, 2008, (21): 4-8.

[22] 宋连春, 杨兴国, 韩永翔, 白虎志. 甘肃气象灾害与气候变化问题的初步研究. 干旱气象, 2006, 24(2): 63-69.

[23] 周生贤. 全面加强沿海防护林体系建设 加快构筑我国万里海疆的绿色屏障一一在全国沿海防护林体系建设座谈会上的讲话. 世界林业 研究, 2005, 18(4): 1-6.

［24］李育才. 西部生态建设急需防沙治沙的法律保障. 中国绿色时报, 2000-11-24(01).

[25］马国青, 宋菲.三北防护林工程区森林状况综合评价. 干旱区资源与环境, 2004，18(5) : 108-111.

[26］康立新, 王述礼. 沿海防护林体系生态效益研究概述. 江苏林业科技, 1995, 22(3): 1-5.

[27] 李世东, 陈应发. 论长江中上游防护林体系建设(I). 防护林科技, 1999, (3) : 25-27, 34-34.

[28］曹玉昆, 吕田，陈宁静. 天然林保护工程政策对中国现行林业政策的影响分析. 林业经济问题, 2011, 31 (5) : 377-382, 391-391.

[29］王质涁. 生态经济型防护林体系是三北防护林工程建设的核心. 防护林科技, 1993，(4): 33-36.

[30］覃庆锋, 陈晨, 曾宪芷, 贺佳飞. 长江流域防护林体系工程建设 30 年回顾与展望. 中国水土保持科学, 2018, 16(5)：145-152.

[31] 普建明. 试论天然林资源保护与国家生态安全. 林业调查规划, 2002, 27(3): 80-83.

[32] 吴运连, 谢国华. 赣州山水林田湖草生态保护修复试点的实践与创新. 环境保护, 2018, 46(13): 80-83.

[33] 支玲, 刘俊昌, 华春. 退耕还林 (草) 的含义与实施基础的研究. 世界林业研究, 2002, 15(6): 69-75.

[34] 杨旭东, 杨春, 孟志兴. 我国草原生态保护现状、存在问题及建议. 草业科学, 2016, 33(9) : 1901- 1909.

[35] 张进德. 科学实施山水林田湖草生态保护与修复工程. 水文地质工程地质, 2018, 45(3) : 3-3.

[36］张蕾. 半个世纪的奋进一一中国林业 50 年发展成就和展望. 中国林业, 1999, (10): 4-7.

[37］陈建成, 程宝栋, 印中华. 生态文明与中国林业可持续发展研究. 中国人口・资源与环境, 2008，18(4)：139-142.

[38] 李文卿, 胡自治, 龙瑞军, 高新才, 李发弟. 甘肃省退牧还草工程实施绩效、存在问题和对策. 草业科学, 2007, 24(1): 1-6.

[39］宗锦耀. 如何实施退牧还草工程. 中国牧业通讯, 2005, (7) : 10-13.

[40］黄娟. 新时代社会主要矛盾下我国绿色发展的思考一一兼论绿色发展理念下“五位一体”总体布局. 湖湘论坛, 2018, 31(2): 60-69.

[41］马亚亚, 刘国彬, 张超, 王杰. 陕北安塞县生态与经济系统耦合协调发展. 生态学报, 2019, 39(18): 6840-6849.

[42] 王洪军, 黄石竹. 林业生态工程建设的经验与问题. 黑龙江生态工程职业学院学报, 2009, 22(1) : 3-4, 16-16.

[43] 董晖. 中国林业生态工程管理问题探讨. 绿色中国, 2004, (2) : 36-40.

[44] 胡莽, 胡文杰, 王刚. 试论西部地区林业生态工程建设存在的问题及其对策. 防护林科技, 2003, (4) : 30-31.

［45］王艳华, 乔颖丽. 退牧还草工程实施中的问题与对策. 农业经济问题, 2011，32(2)：99-103.

[46] 金莲, 王永平. 贵州省生态移民经济可持续发展研究. 山地学报, 2019, 37(1): 98-108.

[47] 魏轩, 周立华, 韩张雄, 王娅, 陈勇, 杨国靖. 生态脆弱区生态工程效益中外评价的比较研究. 生态学报, 2020, 40(1): 377-383.

[48] 刘红. 三江源生态移民补偿机制与政策研究. 中南民族大学学报: 人文社会科学版, 2013, 33(6): 101-105.

[49] 肖锐, 徐润. 易地扶贫搬迁政策实践及其完善. 中南民族大学学报: 人文社会科学版, 2020, 40(2) : 73-77.

[50] 马晓东, 王冰洁. 浅析国家公园体系管理体制中的制度创新一以三江源国家公园为例. 西安建筑科技大学学报: 社会科学版, 2019, $38(3): 58-62$.

[51］李萍. 试析加强林业生态工程建设的技术措施. 农业与技术, 2018, 38(20)：177-177. 